\title{
MARKET ASSESSMENT AND TECHNICAL FEASIBILITY STUDY OF PRESSURIZED FLUIDIZED BED COMBUSTION ASH USE
}

Topical Report

Reporting Period March 1996 - March 1997

By
A. E. Bland
T. H. Brown

April 1997

Work Performed Under Cooperative Agreement

DE-FC21-93MC30127 Task 11

For

Foster Wheeler Energy International, Inc.

Livingston, New Jersey

And

U.S. Department of Energy

Office of Fossil Energy

Federal Energy Technology Center

Morgantown, West Virginia

By

Western Research Institute

Laramie, Wyoming 


\section{DISCLAIMER}

This report was prepared as an account of work sponsored by an agency of the United States Government. Neither the United States Government nor any agency thereof, nor any of their employees, make any warranty, express or implied, or assumes any legal liability or responsibility for the accuracy, completeness, or usefulness of any information, apparatus, product, or process disclosed, or represents that its use would not infringe privately owned rights. Reference herein to any specific commercial product, process, or service by trade name, trademark, manufacturer, or otherwise does not necessarily constitute or imply its endorsement, recommendation, or favoring by the United States Government or any agency thereof. The views and opinions of authors expressed herein do not necessarily state or reflect those of the United States Government or any agency thereof. 


\section{DISCLAIMER}

Portions of this document may be illegible in electronic image products. Images are produced from the best available original document. 


\section{ACKNOWLEDGMENTS}

The authors acknowledge the support of Foster Wheeler Energy International, Inc.; and the U. S. Department of Energy (DOE) Federal Energy Technology Center (FETC), under Cooperative Agreement Number DE-FC21-93MC30127. The authors also wish to acknowledge the support of Electric Power Research Institute during the early phases of the research; the contribution of American Electric Power Services for supplying the ashes from AEP Tidd; Kumar M. Sellakumar of Foster Wheeler Energy International, Inc. for his suggestions and assistance; and Kamal Das of the U.S. Department of Energy Federal Energy Technology Center for his project support and assistance.

\section{DISCLAIMER}

This report was prepared as an account of work sponsored by an agency of the United States Government. Neither the United States Government nor any agencies thereof, nor any of its employees makes any warranty, expressed or implied, or assumes any legal liability or responsibility for the accuracy, completeness, or usefulness of any information, apparatus, product, or process disclosed or represents that its use would not infringe on privately owned rights. Reference herein to any specific commercial product, process, or service by trade name, trademark, manufacturer, or otherwise does not necessarily constitute or imply endorsement, recommendation, or favoring by the United States Government or any agency thereof. The views and opinions of authors expressed herein do not necessarily state or reflect those of the United States Government or any agency thereof. 


\section{TABLE OF CONTENTS}

Page

LIST OF TABLES

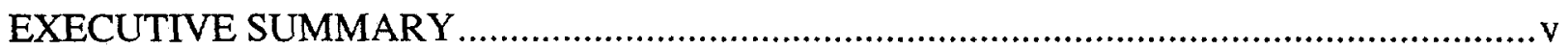

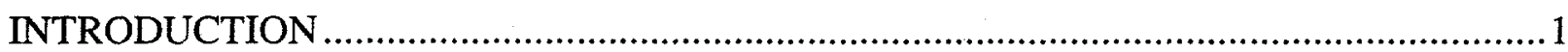

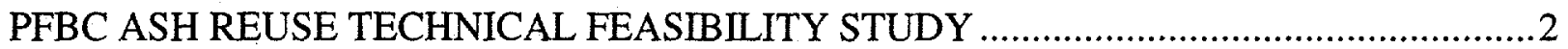

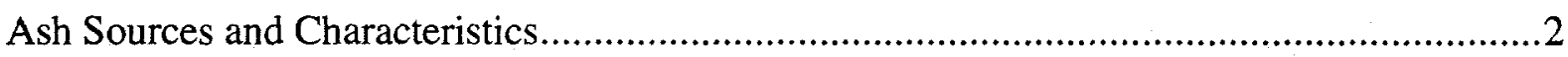

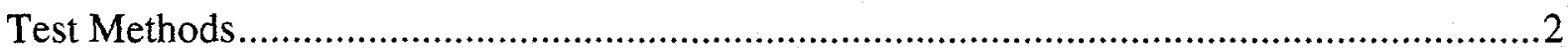

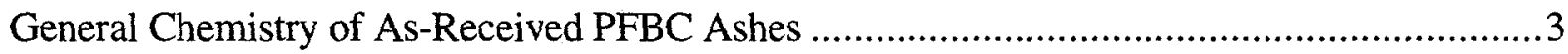

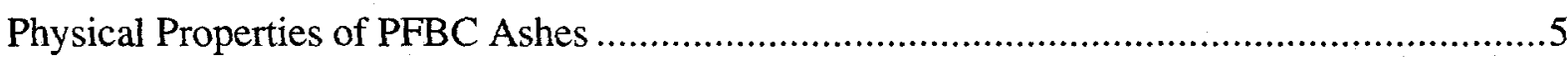

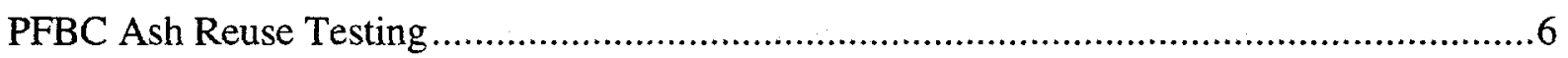

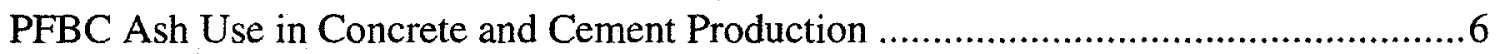

PFBC Ash Use as Structural Fill and Embankment Materials ..........................................

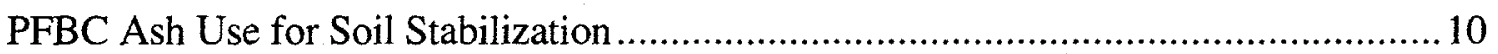

PFBC Ash Use in Synthetic Aggregate Production ................................................12

Ash Use in Soil/Mine Spoil Amendment Applications .................................................13

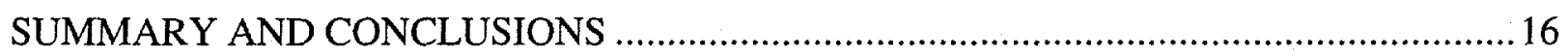

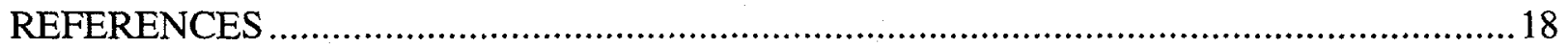




\section{LIST OF TABLES}

Table

Page

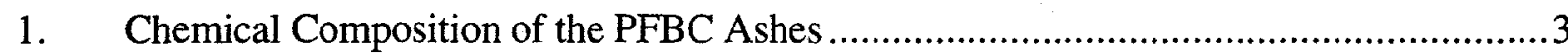

2. Summary of the TCLP Leachate Analysis for PFBC Ashes...........................................

3. Summary of the Bulk Densities and Specific Gravities of the PFBC Ashes.....................5

4. Results of ASTM C-311 Testing of Karhula and AEP Tidd Fly Ashes as Pozzolans

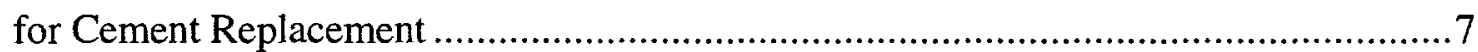

5. Summary of PFBC Ash Use in Type IP Blended Hydraulic Cement-Chemical

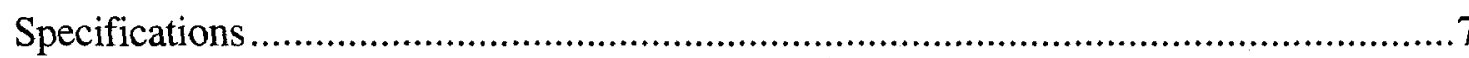

6. Summary of the Moisture-Density Relationships for the PFBC Ashes ...........................9

7. Summary of Properties of Flowable Fill Materials Made with Karhula and AEP Tidd PFBC Ash. 10

8. Summary of the Properties of PFBC Ash-Based Synthetic Aggregate.... 13 


\section{EXECUTIVE SUMMARY}

Pressurized fluidized bed combustion (PFBC) of coal is undergoing demonstration and commercial deployment in the United States, as well as throughout the world. American Electric Power's (AEP) bubbling PFBC $70 \mathrm{MWe}$ Tidd demonstration program in Ohio and pilot-scale development at Foster Wheeler Energia Oy $10 \mathrm{MW}$ th circulating PFBC at Karhula, Finland, have demonstrated the advantages of PFBC technology. Development of uses for solid wastes from PFBC coal conversion systems is being actively pursued as part of the commercial demonstration of PFBC technologies. Ashes collected from Foster Wheeler Energia Oy pilot circulating PFBC tests in Karhula, Finland, operating on (1) low-sulfur subbituminous and (2) high-sulfur bituminous coal and ash from the AEP's high-sulfur bituminous coal-fired bubbling PFBC in Brilliant, Ohio, were evaluated in laboratory and pilot-scale ash-use testing at Western Research Institute (WRI).

Ash use options evaluated for these PFBC ashes were construction-related applications, such as (1) cement production, (2) fills and embankment, (3) soil stabilization, (4) synthetic aggregate production, as well as an amendment for acidic and sodic soil and mine spoil. Testing has concluded the following:

- PFBC ash does not meet the American Society for Testing and Materials (ASTM) chemical requirements as a pozzolan for cement replacement (ASTM C-618). However, potential exists for its use as a pozzolan and as a set-retardant (gypsum replacement) in Type $\mathrm{P}$ portland cement production.

- PFBC ash shows relatively high strength development ( $>400 \mathrm{psi})$, low expansion $(<0.01 \%)$ and low permeabilities $\left(\mathrm{k}<10^{-5} \mathrm{~cm} / \mathrm{sec}\right)$, making it a viable fill and embankment material.

- Lime-enhanced (e.g., 3.6\% $\mathrm{CaO}$ added) PFBC ash develops high strengths ( $>4,000 \mathrm{psi}$ ), manageable early expansion ( $<1.5 \%$ in 7 days), and wet-dry and freeze-thaw cycle durability $(>1 \%$ loss after 12 cycles), making PFBC ash a suitable agent for soil stabilization applications.

- Synthetic aggregate produced with lime-enhanced PFBC ash develops high crush strengths (>300 lbs), Los Angeles (LA) abrasion resistance (10 to 30\% loss) and soundness resistance $(<5 \%)$, making it an excellent material for synthetic aggregate production for construction applications. 
- Laboratory equilibrium studies and greenhouse studies using Garrison Meadow foxtail grass showed PFBC ash to be as effective as ag-lime in promoting seed germination and acid neutralization and more effective than ag-lime in promoting plant productivity and root penetration in acidic spoil. Permeability testing of sodic spoil indicated that PFBC ash was effective in modifying soil structure, resulting in the potential enhancement of root penetration and nutrient availability.

In summary, PFBC ash appears to be a viable material for use in a number of constructionrelated applications, as well as a viable amendment for acidic and sodic soils and mine spoils encountered in the agriculture and mining industries. 


\section{INTRODUCTION}

Pressurized fluidized bed combustion (PFBC) represents one of the most promising emerging Clean Coal Technologies (CCT). PFBC has been demonstrated at near commercial scale at the American Electric Power (AEP) Tidd bubbling PFBC demonstration plant in Ohio, as well as at Vartan in Sweden, and Escatron in Spain. Circulating PFBC technology is being demonstrated at the pilot-scale at Foster Wheeler Energia Oy in Karhula, Finland.

The utilization of ash from fluidized bed combustion (FBC) units is a promising ash management option. The chemical characteristics of pressurized fluidized bed combustion ash compared to other FBC ashes have generated interest in the use of PFBC ash for various construction and agricultural applications. However, before commercial entities are ready to commit to the concept of using PFBC ash, its performance in viable applications must be documented.

Western Research Institute (WRI) is completing a three-year project under sponsorship of the Electric Power Research Institute (EPRI), Foster Wheeler Energy International, Inc., and the U.S. Department of Energy (DOE) Federal Energy Technology Center (FETC) that addresses ash use markets and options for PFBC technologies.

The overall objectives of this study are to determine the market potential and the technical feasibility of using PFBC ash in high-volume use applications. The study is of direct use to the utility industry in assessing the economics of PFBC power generation, particularly in light of ash disposal avoidance achieved through ash use. Additional benefits can be realized by a utility through $\mathrm{CO}_{2}$ offset credits resulting from ash penetration into certain markets that generate high levels of greenhouse gases during manufacturing (e.g., cement production).

The specific objectives of the program are:

- to define present and future market potential of PFBC ash for a range of applications;

- to assess the technical feasibility of PFBC ash use in construction and soil/spoil amendment applications; and

- to demonstrate the most promising of the ash use options in full-scale field demonstrations.

This report addresses the results of the technical feasibility of ash use options for PFBC units using low-sulfur and high-sulfur coal and limestone sorbent-derived ashes (Karhula-low ashes and Karhula-high ashes) and high-sulfur coal and dolomite sorbent-derived ash (AEP Tidd ash). 


\section{PFBC ASH REUSE TECHNICAL FEASIBILITY STUDY}

\section{Ash Sources and Characteristics}

The study of PFBC ash use options has included three different ashes: (1) ash from the Foster Wheeler Energia Oy circulating PFBC pilot plant in Karhula Finland, burning low-sulfur subbituminous coal; (2) ash from the Foster Wheeler Energia Oy circulating PFBC pilot plant in Karhula, Finland, burning high-sulfur bituminous coal; and (3) ash from the AEP Tidd demonstration plant, burning high-sulfur bituminous coal. Two sets of fly ash and bed ash from the Foster Wheeler Energia Oy pilot-scale circulating PFBC unit in Karhula, Finland, represented the combustion of low-sulfur Powder River Basin subbituminous coal (Black Thunder) with limestone sorbent and the combustion of high-sulfur Illinois Basin coal with a limestone sorbent. Fly ash and bed ash from the AEP Tidd facility in Brilliant, Ohio, represent ash from the bubbling PFB combustion of high-sulfur Ohio No. 8 (Illinois Basin) coal and Plum Run dolomite.

\section{Test Methods}

The major element chemistry of the fly ash and bed ash from each of the PFBC sources was determined by X-ray fluorescence, using standard calibration curves. Phase identification of the fly ashes and bed ashes was determined by X-ray diffraction (XRD), wet chemical methods described by American Society for Testing and Materials (ASTM) C-25, and methods described by Iribarne (1993).

Geotechnical testing was conducted according to ASTM procedures on a blend of the fly ash and bed ash combined in relative proportions as produced during combustion. This material is termed an ash blend. Moisture-density relationships were determined according to ASTM D698 compactive effort. Test specimens of the ash blend were prepared at the optimum moisture and densities determined by the ASTM D-698 tests. Specimens of the conditioned and compacted PFBC ash blends were prepared and cured under three curing conditions: (1) sealed conditions; (2) in ash saturated solutions at $23^{\circ} \mathrm{C}$; and (3) in ash-saturated solutions at $5^{\circ} \mathrm{C}$. Ash-saturated solutions were generated by saturating the $\mathrm{PFBC}$ ash in water in a 10:1 water-tosolids ratio. The resulting solution is representative of the water quality that would be generated in a disposal cell or in the area of ash reuse. The specimens that were to be cured in ash saturated solutions were allowed to seal cure for 14 days before being introduced to the saturated curing environment. After curing for a specified curing period, test specimens were tested for unconfined compressive strength and linear expansion, according to ASTM C-109 and C-157 procedures. A portion of each of the tested specimens from the unconfined compressive strength 
testing was washed with acetone to cease the hydration reactions, then analyzed for hydration reaction phases. The hydration reaction phases in the ashes were determined according to a number of techniques, including X-ray diffraction, thermogravimetric analysis (TGA), and scanning electron microscopy (SEM).

\section{General Chemistry of As-Received PFBC Ashes}

The chemical compositions of the Karhula and AEP Tidd ashes are presented in Table 1. The loss on ignition (LOI) is composed of the moisture and the organic and mineral carbon. The LOI in the PFBC ashes is composed principally of mineral carbon. Moistures are less than $0.1 \%$ and the organic carbon contents are less than $3 \%$. The free lime $(\mathrm{CaO})$ content of the PFBC ashes was determined by ASTM C-25 to be in the range of 0.5 to $1.0 \%$. The majority of the lime appears to be carbonated in the form of $\mathrm{CaCO}_{3}$. With the exception of the relatively high mineral carbon, the chemistry of the PFBC ashes is typical of ashes from FBC of low-sulfur and high-sulfur coals using limestone and dolomite sorbents. The chemical characteristics of the fly ashes and bed ashes from each of the three ash sources are presented in Table 1. With the exception of relatively high mineral carbon, the chemistry of the PFBC ashes is typical of ashes from FBC of low-sulfur and high-sulfur coals using limestone and dolomite sorbents. The chemical compositions of the Karhula-low and AEP Tidd ashes have been presented in Bland et al., (1997a and b).

Table 1. Chemical Composition of the PFBC Ashes

\begin{tabular}{|l|cc|cc|cc||}
\hline Chemical & \multicolumn{2}{|c|}{ Karhula-Low } & \multicolumn{2}{c|}{ Karhula-High } & \multicolumn{2}{c|}{ AEP Tidd } \\
Parameter, wt. \% & Fly Ash & Bed Ash & Fly Ash & Bed Ash & Fly Ash & Bed Ash \\
$\mathrm{SiO}_{2}$ & 37.84 & 47.02 & 29.46 & 6.15 & 25.65 & 8.35 \\
$\mathrm{TiO}_{2}$ & 0.87 & 0.40 & 0.43 & 0.12 & 0.49 & 0.13 \\
$\mathrm{Al}_{2} \mathrm{O}_{3}$ & 14.27 & 14.57 & 12.48 & 4.20 & 11.23 & 3.18 \\
$\mathrm{Fe}_{2} \mathrm{O}_{3}$ & 4.95 & 3.80 & 8.69 & 1.33 & 12.51 & 1.58 \\
$\mathrm{CaO}$ & 21.61 & 16.13 & 23.50 & 42.68 & 16.94 & 31.33 \\
$\mathrm{MgO}$ & 3.07 & 2.23 & 0.84 & 0.52 & 9.39 & 18.45 \\
$\mathrm{~K}_{2} \mathrm{O}$ & 0.97 & 2.09 & 1.27 & 0.05 & 1.24 & 0.14 \\
$\mathrm{Na}_{2} \mathrm{O}$ & 1.55 & 2.37 & 1.07 & 0.51 & 0.58 & 0.35 \\
$\mathrm{P}_{2} \mathrm{O}_{5}$ & 0.76 & 0.50 & 0.50 & 0.95 & 0.25 & 0.34 \\
$\mathrm{SO}_{3}$ & 12.17 & 9.39 & 20.83 & 23.56 & 10.55 & 31.31 \\
$\mathrm{LOI}$ & 0.81 & 2.08 & 0.82 & 19.83 & 11.08 & 4.76 \\
Total & 99.37 & 99.76 & 99.89 & 99.70 & 99.91 & 99.92 \\
\hline
\end{tabular}

(1) Karhula-low are ashes from the combustion of low-sulfur subbituminous coal in Karhula facility

(2) Karhula-high are ashes from the combustion of high-sulfur bituminous coal in Karhula facility 
Phase analyses of the ashes were conducted by X-ray diffraction. The Karhula ashes are composed principally of anhydrite $\left(\mathrm{CaSO}_{4}\right)$, calcite $\left(\mathrm{CaCO}_{3}\right)$, coal ash oxides, and dehydroxylated clays. In addition to these phases, the Tidd ashes contain dolomite $\left((\mathrm{Ca}, \mathrm{Mg})_{2} \mathrm{CO}_{3}\right)$ and periclase $(\mathrm{MgO})$, reflecting the use of a dolomite sorbent. It should be noted that the dolomite is principally in the fly ash, while periclase is principally in the bed ash. The dolomite in the fly ash is probably the result of fine dolomite sorbent being blown through the system without the chance to calcine and interact with the gaseous constituents $(8,10)$.

The lack of lime $(\mathrm{CaO})$ in the PFBC ashes is distinctly different from AFBC ashes, which contain large amounts of lime. In PFBC systems, the partial pressure of $\mathrm{CO}_{2}$ favors both calcination and recarbonization. This results in low lime and high carbonates (calcite) in pressurized FBC ash, compared to high lime and low carbonates in the atmospheric FBC ash.

The chemical characteristics of the leachates generated by the Toxicity Characteristics Leaching Procedure (TCLP) were also determined for the bed ash and fly ash from each of the ash sources. These data are presented in Table 2. The data substantiate that none of the leachates generated from the PFBC ashes exceed the Resource Conservation and Recovery Act (RCRA) limits. As such, these ashes would NOT be classified as hazardous. Ashes from coalfired power plants are already categorized as nonhazardous and have been given a exclusion from these RCRA requirements.

Table 2. Summary of the TCLP Leachate Analysis for PFBC Ashes

\begin{tabular}{|c|c|c|c|c|c|}
\hline \multirow[t]{2}{*}{$\begin{array}{l}\text { Chemical } \\
\text { Parameter }\end{array}$} & \multirow{2}{*}{$\begin{array}{l}\text { Regulatory } \\
\text { Limit, } \\
\text { mg/L }\end{array}$} & \multicolumn{2}{|c|}{$\begin{array}{c}\text { Low-Sulfur } \\
\text { Karhula }\end{array}$} & \multicolumn{2}{|c|}{$\begin{array}{l}\text { AEP } \\
\text { Tidd }\end{array}$} \\
\hline & & Fly Ash & Bed Ash & Fly Ash & Bed Ash \\
\hline Arsenic (As) & 5.0 & 0.041 & 0.035 & 0.064 & $<0.005$ \\
\hline Barium (Ba) & 100 & 0.395 & 0.241 & 0.091 & 0.136 \\
\hline Cadmium (Cd) & 1.0 & $<0.010$ & $<0.010$ & $<0.010$ & $<0.010$ \\
\hline Chromium $(\mathrm{Cr})$ & 5.0 & 0.014 & $<0.008$ & $<0.008$ & $<0.008$ \\
\hline Lead $(\mathrm{Pb})$ & 5.0 & $<0.100$ & $<0.100$ & $<0.100$ & $<0.100$ \\
\hline Mercury $(\mathrm{Hg})$ & 0.2 & $<0.002$ & $<0.002$ & $<0.002$ & $<0.002$ \\
\hline Selenium (Se) & 1.0 & $<0.200$ & $<0.200$ & $<0.200$ & $<0.200$ \\
\hline Silver $(\mathrm{Ag})$ & 5.0 & $<0.010$ & $<0.010$ & $<0.010$ & $<0.010$ \\
\hline Initial $\mathrm{pH}$ & na & 9.2 & 8.0 & 9.1 & 10.5 \\
\hline Final pH & na & 9.0 & 7.8 & 8.2 & 9.6 \\
\hline
\end{tabular}

na - not applicable 


\section{Physical Properties of PFBC Ashes}

The general physical properties of the ashes were also determined, including particle size distribution, specific gravity, and bulk densities. The bulk density and specific gravity of the asreceived ashes are presented in Table 3.

Table 3. Summary of the Bulk Densities and Specific Gravities of the PFBC Ashes

\begin{tabular}{||l||c|c|c||}
\hline $\begin{array}{l}\text { Physical } \\
\text { Properties }\end{array}$ & $\begin{array}{c}\text { Minimum Bulk Density, } \\
\mathbf{k g} / \mathbf{m} 3 \text { (pcf) }\end{array}$ & $\begin{array}{c}\text { Maximum Bulk Density, } \\
\mathbf{k g} / \mathbf{m} 3 \text { (pcf) }\end{array}$ & $\begin{array}{c}\text { Specific Gravity } \\
\text { g/cc }\end{array}$ \\
\hline $\begin{array}{l}\text { Karhula-Low } \\
\text { Fly Ash }\end{array}$ & $948(59.2)$ & $1162(72.5)$ & 2.34 \\
Bed Ash & $1368(85.4)$ & $1528(95.4)$ & 2.55 \\
Karhula-High & & & \\
Fly Ash & $795(49.6)$ & $1051(65.6)$ & 2.73 \\
Bed Ash & $1289(80.5)$ & $1397(87.2)$ & 2.81 \\
AEP Tidd & & & \\
Fly Ash & $854(53.3)$ & $1190(74.3)$ & 2.76 \\
Bed Ash & $1285(80.2)$ & $1443(90.1)$ & 2.98 \\
\hline
\end{tabular}

(1) Karhula-low are ashes from the combustion of low-sulfur subbituminous coal in Karhula facility

(2) Karhula-high are ashes from the combustion of high-sulfur bituminous coal in Karhula facility

The size distribution is similar to that of other FBC ashes reported in the literature (Georgiou et al. 1993, Bland et al. 1993b and Bigham et al. 1993). The bulk densities of the Karhula-low, Karhula-high, and AEP Tidd fly ashes and bed ashes were determined according to ASTM procedures.

The bulk densities for the Karhula-low ashes were $948 \mathrm{~kg} / \mathrm{m}^{3}(59.2 \mathrm{pcf})$ (poured) and $1162 \mathrm{~kg} / \mathrm{m}^{3}\left(72.5 \mathrm{pcf}\right.$ ) (packed) for the fly ash and $1368 \mathrm{~kg} / \mathrm{m}^{3}(85.4 \mathrm{pcf}$ ) (poured) and 1528 $\mathrm{kg} / \mathrm{m}^{3}$ (95.4 pcf) (packed) for the bed ash. Bulk densities for the Karhula-high ashes were 795 $\mathrm{kg} / \mathrm{m}^{3}(49.6 \mathrm{pcf})$ (poured) and $1051 \mathrm{~kg} / \mathrm{m}^{3}(65.6 \mathrm{pcf}$ ) (packed) for the fly ash and 1289 $\mathrm{kg} / \mathrm{m}^{3}(80.5 \mathrm{pcf}$ ) (poured) and 1397 (87.2 pcf) (packed) for the bed ash, and those for the Tidd ash were $854 \mathrm{~kg} / \mathrm{m}^{3}$ (53.3 pcf) (poured) and $1190 \mathrm{~kg} / \mathrm{m}^{3}(74.3 \mathrm{pcf}$ ) (packed) for the fly ash and $1285 \mathrm{~kg} / \mathrm{m}^{3}\left(80.2 \mathrm{pcf}\right.$ ) (poured) and $1443 \mathrm{~kg} / \mathrm{m}^{3}(90.1 \mathrm{pcf}$ ) (packed) for the bed ash.

Specific gravities for the Karhula-low fly ash and bed ash materials were determined to be 2.3 and $2.6 \mathrm{~g} / \mathrm{cc}$, respectively, the specific gravities of the Karhula-high fly ash and bed ash were $2.7 \mathrm{~g} / \mathrm{cc}$ and $2.8 \mathrm{~g} / \mathrm{cc}$, respectively, while the specific gravities of the Tidd fly ash and bed ash were $2.8 \mathrm{~g} / \mathrm{cc}$ and $3.0 \mathrm{~g} / \mathrm{cc}$, respectively. 


\section{PFBC Ash Reuse Applications Testing}

Laboratory and pilot-scale tests were conducted to address the use of Karhula and Tidd PFBC ash in a number of construction-related applications, including (1) cement replacement and cement manufacturing, (2) fills and embankment construction, (3) soil stabilization applications, and (4) synthetic aggregate production.

\section{PFBC Ash Use in Concrete and Cement Production}

The use of PFBC ash appears to be technically feasible in the cement industry. PFBC ash may be used in concrete and in cement production, including (1) as a replacement for cement in portland cement concrete; or (2) as a pozzolanic material in the production of pozzolanic cements (e.g., Type IP); and (3) as a set retardant interground with cement as a replacement for gypsum.

The concrete and cement markets for PFBC ash are very large. Over 6.6 million tonnes (6 million tons) of fly ash are used annually as a replacement for portland cement in ready-mix concrete and concrete products. Approximately $42 \%$ of all ready-mix concrete contains fly ash at an average of $20 \%$ replacement of the cement. In addition, in 1992, over 88 million tonnes (80 million tons) of portland cement were produced in the United States, consuming approximately 1.1 million tonnes ( 1 million tons) of fly ash in the production of pozzolanic cement.

Cement Replacement. The use of PFBC ash in concrete and concrete products relies on the pozzolanic property of the ash. Fly ash, including FBC ash, is known to be a pozzolan and therefore is used as a cement replacement in portland cement concrete. The use of PFBC ash as a pozzolan for portland cement and concrete products is dependent on a number of characteristics that are tested according to methods of ASTM C-311 and must comply with the specifications of ASTM C-618. The fly ashes from Karhula and AEP Tidd were analyzed for chemical and physical properties related to their use as pozzolans for cement replacement in portland cement and concrete products. The results are presented in Table 4. The data indicate that the ashes do not qualify as pozzolans according to ASTM C-311 because the sulfate levels exceed the ASTM C-618 specification of 5\% maximum $\mathrm{SO}_{3}$ content. This will restrict the use of certain PFBC ashes as pozzolans for portland cement applications. 
Table 4. Results of ASTM C-311 Testing of Karhula and AEP Tidd Fly Ashes as Pozzolans for Cement Replacement

\begin{tabular}{|c|c|c|c|c|c|}
\hline & \multirow{2}{*}{$\begin{array}{c}\text { Karhula- } \\
\text { Low } \\
\text { Fly Ash }\end{array}$} & \multirow{2}{*}{$\begin{array}{c}\text { Karhula- } \\
\text { High } \\
\text { Fly Ash }\end{array}$} & \multirow{2}{*}{$\begin{array}{c}\text { AEP } \\
\text { Tidd } \\
\text { Fly Ash }\end{array}$} & \multicolumn{2}{|c|}{$\begin{array}{l}\text { ASTM C-618 } \\
\text { Specifications }\end{array}$} \\
\hline & & & & Class F & Class $\mathrm{C}$ \\
\hline \multicolumn{6}{|l|}{ Chemical Properties } \\
\hline $\mathrm{SiO}_{2}+\mathrm{Al}_{2} \mathrm{O}_{3}+\mathrm{Fe}_{2} \mathrm{O}_{3}$, wt. $\%$ & 57.57 & 50.63 & 49.39 & $70 \mathrm{~min}$ & $50 \mathrm{~min}$ \\
\hline Sulfur Trioxide, wt. $\%$ & 12.17 & 20.83 & 10.55 & $5 \max$ & $5 \max$ \\
\hline Calcium Oxide, wt. \% & 21.6 & 23.5 & 16.9 & & \\
\hline Moisture Content, wt. \% & 0.09 & 0.15 & 0.11 & $3 \max$ & $3 \max$ \\
\hline Loss on Ignition, wt. \% & 0.81 & 0.82 & 11.08 & $6 \max$ & $6 \max$ \\
\hline Available Alkalis, wt.\% & 0.70 & 1.16 & 0.68 & $1.5 \max$ & $1.5 \max$ \\
\hline \multicolumn{6}{|l|}{ Physical Properties } \\
\hline Fineness, \% retained 325 mesh & 25.58 & 37.83 & 21.97 & $34 \max$ & $34 \max$ \\
\hline \multicolumn{6}{|l|}{ Pozzolanic Activity Index } \\
\hline With PC*,\% of control @ 28 days & 83.4 & 59.4 & 89.8 & $75 \mathrm{~min}$ & $75 \mathrm{~min}$ \\
\hline Water Requirement, $\%$ of control & 97.7 & 102.5 & 98.3 & $105 \max$ & $105 \max$ \\
\hline Soundness - Autoclave Expansion, \% & -0.040 & -0.059 & 0.000 & $0.8 \max$ & $0.8 \max$ \\
\hline Drying Shrinkage Increase @ 28 days,\% & 0.016 & 0.027 & 0.011 & $0.03 \max$ & $0.03 \max$ \\
\hline
\end{tabular}

*PC - portland cement

(1) Karhula - low are ashes from the combustion of low-sulfur subbituminous coal in Karhula facility

(2) Karhula - high are ashes from the combustion of high-sulfur bituminous coal in Karhula facility

Portland Cement Production. PFBC ash can be incorporated into the cement manufacturing process as an ingredient in the clinker production and secondly as an interground material in the production of Type IP pozzolanic cements. The characteristics of the ash for these applications are defined under ASTM C-595 and C-593. The use of ash as a pozzolan in blended cement according to ASTM C-595 does not rely on the chemical properties of the pozzolan and instead is based on performance specifications for the resultant blended cement. Calculations related to the potential use of the PFBC ashes in the manufacturing of blended Type IP cement are presented in Table 5. It is clear that PFBC ash could be used in substantial amounts in Type IP portland cement.

\section{Table 5. Summary of PFBC Ash Use in Type IP Blended Hydraulic Cement-Chemical Specifications}

\begin{tabular}{|l|c|c|c|c|}
\hline $\begin{array}{l}\text { Chemical } \\
\text { Requirements }\end{array}$ & $\begin{array}{c}\text { Karhula -Low } \\
\text { Fly Ash1 }\end{array}$ & $\begin{array}{c}\text { Karhula-High } \\
\text { Fly Ash1 }\end{array}$ & $\begin{array}{c}\text { AEP Tidd } \\
\text { Fy Ash } 2\end{array}$ & $\begin{array}{c}\text { ASTM C-595 } \\
\text { Specifications }\end{array}$ \\
\hline MgO, \% & & & & \\
SO3, \% & 2.9 & 2.5 & 4.0 & $5.0 \mathrm{Max}$. \\
LOI, \% & 2.9 & 2.9 & 2.9 & $4.0 \mathrm{Max}$. \\
Fly Ash Addition, \% & 1.0 & 1.0 & 1.8 & $5.0 \mathrm{Max}$. \\
Gypsum Required, \% & 23.8 & 13.9 & 18.0 & - \\
\hline
\end{tabular}

1. Calculations are based on fly ash interground with Type I portland cement to achieve (1) equivalent of $5 \%$ gypsum addition or (2) a maximum of $4 \% \mathrm{MgO}$ content in cement.

(1) Karhula-low - ashes from the combustion of low-sulfur subbituminous coal in Karhula facility

(2) Karhula-high - ashes from the combustion of high-sulfur bituminous coal in Karhula facility 


\section{PFBC Ash Use as Structural Fill and Embankment Materials}

The application of PFBC residue as an engineered material for structural fills and embankments represents a large-scale use option. Structural fills and embankments are numerous in the road construction, mining, and industrial construction industries.

In addition to these compacted fill applications, PFBC ash is potentially applicable in controlled density low-strength flowable fill (CDLSFF). This material is not really concrete and is highly flowable (slump 9-10 inches). CDLSFF is usually mixed in a ready-mix concrete truck, with mixing continuing during transport to prevent segregation. The CDLSFF is discharged and placed using chutes or can be pumped using standard concrete or grout equipment. A number of applications have been documented for CDLSFF, including excavatable backfills and trench/pipe bedding, structural fills, road bases, caisson and pile fills, and mine void filling. PFBC ash is expected to be marketable in both compacted fill and flowable fill applications.

Geotechnical tests using the ashes from Karhula and AEP Tidd were conducted to determine the possible use of the ashes as compacted structural fill or embankment material, as well as flowable fill material for excavatable trench grade and structural fill applications. A description of the results of testing for each of these engineered fill materials is provided below.

Compacted Fills and Embankments. The geotechnical tests related to compacted structural fills and embankments focused on the moisture-density relationship (Proctors), unconfined compressive strength, expansion and swell, and permeability.

Moisture-density relationships were determined using ASTM D-698 and ASTM D-1557 compactive efforts. The compactive effort employed in the ASTM D-1557 tests is twice that for ASTM D-698. These compactive efforts typically cover the range of compaction achievable with standard construction equipment. The results are presented in Table 6. The lower optimum moisture and higher maximum dry density observed for the bed ash is consistent with the larger particle size and specific gravity of the bed ash relative to the fly ash. The ASTM D698 and D-1557 modified Proctor data are consistent with the expected behavior of different compactive efforts (i.e., lower optimum moisture and higher maximum dry density for increased compactive effort).

Testing also addressed the strength development of the Karhula and AEP Tidd ash blends as related to their use in compacted structural fills and embankments. The ash blends are a composite of the fly ash and the bed ash in approximate proportions to those produced in the combustor. Specimens were prepared at the optimum moisture and densities represented by ASTM D-698 and D-1557 and cured under sealed and saturated (100\% relative humidity) conditions at $23^{\circ} \mathrm{C}$. 
Table 6. Summary of the Moisture-Density Relationships for the PFBC Ashes

\begin{tabular}{|c|c|c|c|c|}
\hline & \multicolumn{2}{|c|}{ ASTM D-698 } & \multicolumn{2}{|c|}{ ASTM D-1557 } \\
\hline & $\begin{array}{c}\text { Optimum } \\
\text { Moisture, \% }\end{array}$ & $\begin{array}{c}\text { Maximum } \\
\text { Dry Density, } \\
\text { kg/m } \mathbf{m}^{3} \text { (pcf) }\end{array}$ & $\begin{array}{c}\text { Optimum } \\
\text { Moisture, \% }\end{array}$ & $\begin{array}{c}\text { Maximum } \\
\text { Dry Density, } \\
\text { kg/m } / \mathbf{m}^{3} \text { (pcf) }\end{array}$ \\
\hline \multicolumn{5}{|l|}{ Karhula-Low (1) } \\
\hline Fly Ash & 28.98 & $1397(87.2)$ & 26.59 & $1488(92.9)$ \\
\hline Ash Blend & 24.83 & $1505(94.0)$ & 21.24 & $1594(99.5)$ \\
\hline \multicolumn{5}{|l|}{ Karhula-High (2) } \\
\hline Fly Ash & 40.21 & $1125(70.2)$ & 31.92 & $1263(78.8)$ \\
\hline Ash Blend & 24.6 & $1413(88.2)$ & 24.83 & $1505(94.0)$ \\
\hline \multicolumn{5}{|l|}{ AEP Tidd } \\
\hline Fly Ash & 24.32 & $1636(102.1)$ & 22.33 & $1656(103.3)$ \\
\hline Ash Blend & 20.08 & $1760(109.9)$ & 17.70 & $1819(113.6)$ \\
\hline
\end{tabular}

nd- not determined

(1) Karhula-low ashes from the combustion of low-sulfur subbituminous coal in Karhula facility

(2) Karhula-high ashes from the combustion of high-sulfur bituminous coal in Karhula facility

Strength development for the Karhula and AEP Tidd ash blends under sealed conditions was determined for different compactive efforts. Strength development is low compared to that of AFBC ash, which is typically 6.9 to $34.5 \mathrm{MPa}$ (1000 to $5000 \mathrm{psi}$ ). The strength development of the Karhula PFBC ash is a factor of 4 to 10 times higher than for other soils and fill materials, while the strength of the AEP Tidd ash was even higher. The differences in strength between the Karhula and AEP Tidd ashes are related to differences in the hydration reaction chemistry of the two ashes (Bland, 1997a). The ASTM D-1557 compacted specimens were stronger than the ASTM D-698 compacted specimens.

The expansion properties of the conditioned and compacted Karhula and AEP Tidd ashes were determined according to modified ASTM C-157 procedures in which the expansion is essentially unrestricted. The results for the Karhula and AEP Tidd ash blends for ASTM D698 and D-1557 compactive efforts are essentially identical, with expansion of near zero percent. In addition, the ASTM D-698 and D-1557 compacted ash blend specimens cured under both sealed and saturated conditions showed essentially no expansion. The Karhula and AEP Tidd ash blends appear to be dimensionally stable and thereby suited for compacted fill and embankment applications.

The permeabilities of the Karhula and AEP Tidd ash blends were determined according to ASTM procedures. The ashes were compacted at ASTM D-698 optimum moisture. As expected, the permeability of the ash blends continued to decrease with curing. Hydraulic conductivities in the range of $9 \times 10^{-6} \mathrm{~cm} / \mathrm{sec}$ were determined at early ages and continued to 
decrease to values of $2 \times 10^{-6} \mathrm{~cm} / \mathrm{sec}$, after which the values appeared to stabilize. These values are typical of those reported for CFBC ashes (Georgiou et al. 1993).

Controlled Density Low-Strength Flowable Fills. The second application involves controlled density low-strength flowable fill material, which has been used in construction applications for a number of years. Controlled density low-strength flowable fill material is a mixture of cement, fly ash, sand, and water that has a specific strength dependent upon the end use. CDLSFF offers favorable economics compared to other fill materials because it requires less excavation and compaction during construction.

The results of tests using Karhula and AEP Tidd PFBC ashes in CDLSFF are represented in Table 7 . Structural fill grade CDLSFF, requiring in excess of 1200 psi strength, and excavatable trench fill grade, requiring strengths in the range of 700 to $1400 \mathrm{kPa}$ (100 to 200 psi), were tested. The data clearly show that both the Karhula and the AEP Tidd fly ashes can be used as CDLSFF.

Table 7. Summary of Properties of Flowable Fill Materials Made with Karhula and AEP Tidd PFBC Ash

\begin{tabular}{|c|c|c|c|c|c|c|}
\hline \multicolumn{7}{|c|}{$\frac{\text { Excavatable Trench Fill }}{\text { Grade }}$} \\
\hline & $\begin{array}{l}\text { Karhula } \\
\text { Low (1) }\end{array}$ & $\begin{array}{l}\text { Karhula } \\
\text { High (2) }\end{array}$ & $\begin{array}{l}\text { AEP } \\
\text { Tidd }\end{array}$ & $\begin{array}{l}\text { Karhula } \\
\text { Low (1) }\end{array}$ & $\begin{array}{l}\text { Karhula } \\
\text { High (2) }\end{array}$ & $\begin{array}{l}\text { AEP } \\
\text { Tidd }\end{array}$ \\
\hline \multicolumn{7}{|c|}{ Mix Components, $\mathrm{kg} / \mathrm{m}^{3}$} \\
\hline Portland Cement & 113 & 113 & 113 & 48 & 48 & 48 \\
\hline PFBC Fly Ash & 267 & 267 & 267 & 267 & 267 & 267 \\
\hline \multicolumn{7}{|c|}{ Penetration Resistance, kPa } \\
\hline 4 hours & 400 & 538 & 35 & 28 & 476 & 0 \\
\hline 8 hours & 2165 & 786 & 752 & 193 & 896 & 110 \\
\hline 24 hours & 2647 & 2096 & 5419 & 883 & 3916 & 1324 \\
\hline \multicolumn{7}{|c|}{ Compressive Strength, $\mathbf{k P a}$} \\
\hline 2 days & 903 & 317 & 607 & 317 & 524 & 41 \\
\hline 7 days & 2055 & 986 & 2744 & 579 & 1930 & 986 \\
\hline 28 days & 7108 & na & 8266 & 1400 & na & 1613 \\
\hline
\end{tabular}

na-not available

(1) Karhula-low are ashes from the combustion of low-sulfur subbituminous coal in Karhula facility

(2) Karhula-high are ashes from the combustion of high-sulfur bituminous coal in Karhula facility

\section{PFBC Ash Use for Soil Stabilization}

The use of PFBC ash and other FBC residues for stabilization of soils is a potentially large ash use market. This ash use application is similar to the cement stabilization of soils commonly applied in the construction industry. Soil stabilization is based on the treatment of 
clay soils with a material to provide strength and stability. Cement, fly ash, and lime-ash materials are commonly employed at levels of 10 to $20 \%$ of the soil. FBC ashes exhibit selfcementing characteristics and, as such, have been proposed as a viable stabilizing agent.

For a material to be considered as a cementing agent for soil stabilization applications, the material must show strength development, freeze-thaw durability, and wet-dry durability in compliance with ASTM D-1632, D-560, and D-559, respectively. A viable cementing material needs to exhibit strength in the range of 4000 psi and durability of 12 cycles of freeze-thaw and wet-dry for the cementing material only. These requirements result from stabilized soil specifications of $2.76 \mathrm{MPa}(400 \mathrm{psi})$ and durability to 12 cycles of wet-dry and freeze-thaw when soils are treated at 10 to $20 \%$ cementing levels.

Unconfined Compressive Strength Relationship. Testing was conducted using the Karhula and AEP Tidd ash blends with and without hydrated lime addition to determine their potential as a cementing agent for soil stabilization applications. The test specimens were cured under sealed and saturated conditions $\left(23^{\circ} \mathrm{C}\right)$.

The results showed that the addition of $5 \%$ hydrated lime increased the strength development dramatically (over $41.4 \mathrm{MPa}(6,000 \mathrm{psi})$ at 90 days for Karhula ash and over 62 $\mathrm{MPa}(9,000 \mathrm{psi})$ at 90 days for AEP Tidd ash). The ash blend without hydrated lime enhancement showed strengths of less than $6.9 \mathrm{MPa}$ (1000 psi) for the Karhula ash and less than 24.1 $\mathrm{MPa}$ (3,500 psi) for the AEP Tidd ash. As mentioned earlier, these differences in strength are due to differences in the hydration chemistry of the two ashes (Bland, 1997a). The low strengths of the ash blends without lime are sufficient for many applications, such as fills and embankments. However, for other applications, such as soil stabilization, lime enhancement will be required at some level (e.g., $5 \%$ or less).

Expansion Properties. The expansion properties of the conditioned and compacted Karhula and AEP Tidd ashes with and without hydrated lime addition were tested for soil stabilization applications, according to a modified ASTM C-157 procedure. The Karhula and AEP Tidd ashes with and without hydrated lime addition were conditioned and compacted at the ASTM D-698 optimum moisture and proctor density.

The lime-enhanced Karhula ash blend showed expansion of approximately $1.5 \%$, while the ash blend without lime enhancement showed essentially no expansion. The expansion noted for the lime-enhanced ash appears to occur early, within the first 20 to 30 days. Although the expansion is significant, it appears controllable and manageable, and it should be possible to balance the strength and swelling properties in certain applications. For example, in certain 
grouting applications, such as subsidence control in underground construction operations, controlled expansion of the magnitude reported is desirable.

Freeze-Thaw and Wet-Dry Cycles. Conditioned and compacted Karhula and AEP Tidd ash blend specimens were subjected to 12 cycles of freeze-thaw (ASTM D-560) and wet-dry (ASTM D-559) conditions. The results indicated that the Karhula ashes without lime enhancement did not survive the 12 cycles, while those with $5 \%$ lime addition survived the entire 12 cycles with losses less than the $15 \%$ maximum limit. AEP Tidd ash, with and without lime enhancement survived both freeze-thaw and wet-dry cycles. Losses of approximately $1 \%$ were determined for these AEP Tidd ashes. Freeze-thaw and wet-dry cycle durability testing of the Karhula-high ashes is in progress.

\section{PFBC Ash Use in Synthetic Aggregate Production}

The aggregate market encompasses conventional aggregate products, such as masonry units and ready-mix concrete. Also, with crushing, aggregates can be produced for use in asphalt paving, road base construction, and even roller compacted concrete. Lightweight aggregate can also be used in many structural building products.

Synthetic aggregate has been manufactured from power plant ash that can meet the requirements for conventional aggregate products, such as masonry units and ready-mix concrete, and with crushing can be produced for use in asphalt paving, road base construction and even roller-compacted concrete. As such, synthetic aggregate for construction applications appears to be a major market for PFBC ashes, as well as a method for storage of ash in the construction off-season.

Pelletizing Trials. Pelletizing trials were conducted simulating the AET process for the pelletization of FBC ashes, as described in the literature (Bland et al. 1992 and 1993a).

Pelletizing trials have been conducted employing Karhula and AEP Tidd ash blends with and without lime enhancement. The pelletizing trials were conducted to address the water requirement and other processing parameters pertinent to defining the technical feasibility and relative economics of aggregate production from PFBC ashes.

Pelletized Ash Testing. The pelletized aggregate produced from Karhula and AEP Tidd PFBC ash was tested according to ASTM procedures as they relate to its use in various construction applications. Pelletized ash from each of the pelletizing trials was tested for crush strength, Los Angeles abrasion resistance (ASTM C-131) and soundness (ASTM C-88). The 
results of testing are presented in Table 8. Testing using the Karhula-high ash is planned but has not been initiated at the time of this report.

Table 8. Summary of the Properties of PFBC Ash-Based Synthetic Aggregate

\begin{tabular}{|c|c|c|c|c|}
\hline \multirow{2}{*}{$\begin{array}{l}\text { Aggregate } \\
\text { Properties* }\end{array}$} & \multicolumn{2}{|c|}{ No Lime Enhancement } & \multicolumn{2}{|c|}{ Lime Enhancement } \\
\hline & Karhula Ash & AEP Tidd Ash & Karhula Ash & AEP Tidd Ash \\
\hline \multicolumn{5}{|l|}{ Crush Strength, kg } \\
\hline 24 hours & 10.4 & 34.0 & 146.6 & 108.9 \\
\hline 48 hours & 10.9 & 36.8 & 138.8 & 102.5 \\
\hline 7 days & 14.1 & 47.2 & 154.3 & 125.2 \\
\hline 28 days & 23.6 & 74.4 & 131.1 & 127.9 \\
\hline \multicolumn{5}{|l|}{ LA Abrasion Resistance } \\
\hline Grade & $\mathrm{B}$ & $\mathrm{C}$ & $\mathrm{B}$ & $\mathrm{C}$ \\
\hline Loss@28 days, \% & 75.29 & 42.1 & 26.07 & 11.1 \\
\hline \multicolumn{5}{|l|}{ Soundness $* *$} \\
\hline Loss after 5 cycles, $\%$ & 27.97 & 15.08 & -4.23 & 2.35 \\
\hline
\end{tabular}

* Curing conditions $-180^{\circ} \mathrm{F}$ sealed for 24 hours.

** Magnesium sulfate solution.

The results indicate that without hydrated lime addition, the pelletized PFBC ash does not meet the ASTM or American Association of State Highway Transportation Officials (AASHTO) construction aggregate requirements of a maximum of $40 \%$ weight loss. However, the addition of $5 \%$ hydrated lime results in compliance with ASTM and AASHTO requirement for construction aggregate. In addition, the soundness of the aggregate using magnesium sulfate solutions were well below the AASHTO specifications of less than $18 \%$ loss after five cycles. In fact, the Karhula aggregate actually gained weight as a result of continued hydration during the five cycles.

\section{Ash Use in Soil/Mine Spoil Amendment Applications}

PFBC ash use as a soil amendment for agricultural and reclamation activities represents a potentially large market. A number of benefits can result from the application of PFBC residue to agricultural soils or mine spoils, including the modification of soil $\mathrm{pH}$, supply of essential plant micro-nutrients for crop production, increasing water infiltration, and modification of soil structure promoting root growth.

The availability of nutrients, such as sulfur, potassium, and phosphorous, along with micro-nutrients is expected to benefit plant growth. In addition, the neutralization potential of the ash materials can alleviate acid conditions found in many soils. Also, PFBC ash contains 
anhydrite or gypsum, often used to reclaim sodic materials (i.e., materials influenced by high levels of sodium).

PFBC ashes generated at the Karhula and AEP Tidd plants were evaluated as soil amendments to ameliorate acid and sodic conditions on problem soils. As mentioned earlier, this material was thought to be useful because of its high neutralization potential, high $\mathrm{CaSO}_{4}$ content, and nutritional potential. A very important consideration for the use of this material for ameliorating problem soils was the potential for negative impact of other constituents on the environment. Saturated paste extracts have shown that the ash materials do not contain any elements at concentrations deemed harmful to the environment.

Laboratory Equilibration Study. Laboratory equilibration studies were conducted to address the use of PFBC ashes as amendments to ameliorate acidic spoil and soil conditions (Brown et al. 1997). The laboratory equilibration study was designed to determine the potential of the ash materials to neutralize the available acid and the potential acidity associated with oxidation of reduced materials present in the spoil. An acid spoil material from Texas was used for the study. Humidity cells were used to simulate the oxidation of acid-forming soils under amended and non-treated conditions. Ag-lime $\left(\mathrm{CaCO}_{3}\right)$ and Karhula fly ash were used as the soil neutralization amendment materials in the equilibrium humidity cell studies. The acid spoil material was treated with three levels of ag-lime and three levels of Karhula fly ash:

- Level $1=30.4 \mathrm{~g}$ ag-lime or $89.1 \mathrm{~g}$ Karhula fly ash $/ 1000 \mathrm{~g}$ of spoil

- Level $2=26.2 \mathrm{~g}$ ag-lime or $77.4 \mathrm{~g}$ Karhula fly ash/1000 $\mathrm{g}$ of spoil

- Level $3=17.6 \mathrm{~g}$ ag-lime or $51.6 \mathrm{~g}$ Karhula fly ash/1000 g of spoil

The amount of ag-lime used was based on the calcium carbonate equivalent (CCE) of the material and the acid/base accounting values of the acid spoil. The PFBC fly ash application rates were equivalent to the acid neutralization potential used for the ag-lime tests. Treatment of acid soils usually employs an application rate of 1.2 times that calculated from the neutralization potential.

The humidity cell equilibration study showed the Karhula fly ash to be an effective acid neutralization amendment. The acid present in the treated materials was neutralized, and the formation of acid from acid-forming minerals present in the spoil material was significantly reduced due to treatment with $\mathrm{PFBC}$ ashes. 
These results compared well with data collected for the ag-lime treatments. It is apparent that the neutralization reaction rate of the Karhula fly ash in raising $\mathrm{pH}$ of the acid spoil is slower than that of the ag-lime.

While the Karhula fly ash shows a delayed response, the ag-lime reacted immediately with the spoil material, increasing the $\mathrm{pH}$ and maintaining it with time. Although the Karhula fly ash is an effective long-term amendment for acid soils and spoils, the lower early pH levels of approximately 4 for the Karhula fly ash treated spoils may cause some problems with germination and early plant growth with sensitive plant species.

Greenhouse Productivity Study. A greenhouse study was conducted to show the influence of PFBC ashes on the productivity of acidic mine spoil containing very high potential acidity (Brown et al. 1997). The study compared the production of Garrison Meadow foxtail grass (Alopecuras protensis cult. Garrison) on acid spoil materials amended with ash from the Karhula and AEP Tidd operations and with ag-lime $\left(\mathrm{CaCO}_{3}\right)$. The greenhouse study was conducted under controlled conditions of light, temperature, fertilizer levels, and soil moisture requirements to maximize plant growth conditions. Fertilizer additions were based on nitrogen, phosphorous, and potassium levels and did not include concerns for nutrient ratios and micronutrient deficiencies.

The results of the study clearly indicate that extremely poor quality soils can be successfully treated with PFBC ashes, resulting in good plant productivity. Total plant production was about $25 \%$ higher for the Tidd and Karhula ash treatments compared to the aglime treatment at the high level (Level 1) of application. At the low amendment application rate the Karhula treatment resulted in plant production about $30 \%$ higher compared to the Tidd and ag-lime treatments, which were comparable. The results show PFBC ashes to be as effective as ag-lime in promoting seed germination and more effective than ag-lime in promoting plant production and root penetration

An obvious factor responsible for the differences in the plant production between the PFBC ash amended spoils and the ag-lime amended spoil was the root penetration. The PFBC ash treated soils contained root matter throughout the potted soil, while much of the root mass in the ag-lime treated soil was associated with the sides of the pots. No problems with the early low $\mathrm{pH}$ were found.

A second greenhouse study is in progress. This greenhouse study is examining all three of the PFBC fly ashes, in addition to the ag-lime control. The production species will include the following: 
- Common Bermuda grass

- Meadow foxtail grass

The duration of the greenhouse study will be sufficient to allow for three cuttings of the Bermuda grass. The results of this testing are not available for this report.

Sodic Soils Amelioration Study. Permeability testing of sodic spoil materials collected from a mine site in North Dakota indicated that PFBC ash was an effective treatment resulting in the potential for enhanced root penetration and gas and liquid movement within the spoil material. The untreated spoil material allowed no water penetration into the material or movement through the material during the permeability tests. Treated material allowed water penetration and movement through the material at a relatively high rate.

\section{SUMMARY AND CONCLUSIONS}

Western Research Institute, in conjunction with the Electric Power Research Institute, Foster Wheeler International, Inc. and the U.S. Department of Energy, has undertaken a research and demonstration program designed to examine the market potential and the technical feasibility of ash use options for PFBC ashes. Ashes from the Foster Wheeeler Energia Oy pilot-scale circulating PFBC tests in Karhula, Finland, combusting (1) low-sulfur subbituminous and (2) high-sulfur bituminous coal, and ash from the AEP's high-sulfur bituminous coal-fired bubbling PFBC in Brilliant, Ohio, were evaluated in laboratory and pilot-scale ash use testing at WRI.

The technical feasibility study examined the use of PFBC ash in construction-related applications, including its use as a cementing material in concrete and use in cement manufacturing, fill and embankment materials, soil stabilization agent, and use in synthetic aggregate production. Testing was also conducted to determine the technical feasibility of PFBC ash as a soil amendment for acidic and sodic problem soils and spoils encountered in agricultural and reclamation applications.

The results of the technical feasibility testing indicated the following:

- PFBC ash does not meet the chemical requirements as a pozzolan for cement replacement. However, it does appear that potential may exist for its use in cement production as a pozzolan and/or as a set retardant. 
- PFBC ash shows relatively high strength development, low expansion, and low permeability properties that make its use in fills and embankments promising.

- Testing has also indicated that PFBC ash, when mixed with low amounts of lime, develops high strengths, suitable for soil stabilization applications and synthetic aggregate production. Synthetic aggregate produced from PFBC ash is capable of meeting ASTM/AASHTO specifications for many construction applications.

- The residual calcium carbonate and calcium sulfate in the PFBC ash has been shown to be of value in making PFBC ash a suitable soil amendment for acidic and sodic problem soils and mine spoils.

In conclusion, PFBC ash represents a viable material for use in currently established applications for conventional coal combustion ashes. As such, PFBC ash should be viewed as a valuable resource, and commercial opportunities for these materials should be explored for planned PFBC installations. 


\section{REFERENCES}

Bigham, J., W. Dick, L. Forster, F. Hitzhusen, E. McCoy, R. Stehouwer, S.W. Traina, W. Wolfe, and R. Haefner, 1993, "Land Application Uses for Dry FGD By-Products; Phase I Report." U.S. Department of Energy, Morgantown Energy Technology Center.

Bland, A.E., R. Cox, A. Rowen, E.R. Lichty, and R.A. Schumann, 1992, Pelletizing Ash, United States Patent Number 5,137.753, August 11, 1992.

Bland, A.E., R. Cox, A. Rowen, and E.R. Lichty, 1993a, "Pelletization as an Ash Management Option for CFBC Ash Handling and Utilization." Proc., 12th International Conference on Fluidized Bed Combustion, La Jolla, CA, May, 1993, pp 1341-1350.

Bland, A.E, D.N. Georgiou, and E.J. Anthony, 1993b, "Seawater Conditioning of CFBC Ash." Proc., 12th International Conference on Fluidized Bed Combustion, La Jolla, CA, pp 835846.

Bland, A.E. and T.H. Brown, 1997a, "Hydration Reaction Chemistry Associated with Management of Pressurized Fluidized Bed Combustion Ash." Proc., 14th International Conference on Fluidized Bed Combustion, Vancouver, BC, May 11-14, 1997 a.

Bland, A.E., T.H. Brown and J.M. Wheeldon, 1997b, "Pressurized Fluidized Bed-Part I Construction-Related Use Options." FUEL, Vol. 76, pp 730-740.

Bland, A.E., T.H. Brown and J. M. Wheeldon, 1997c, "Pressurized Fluidized Bed-Part II Soil and Mine Spoil Amendment Use Options." FUEL, Vol. 76, pp 741-748.

Georgiou, D.N., A.E. Bland, and D. Sundstrom, 1993, "Laboratory Evaluation of a Low Sulfur Coal CFBC Residue as a Structural Fill." Proc., 12th International Conference on Fluidized Bed Combustion, La Jolla, CA, May, 1993, pp 629-639.

Iribarne, A. P., E. J. Anthony, and J. Blondin, 1993, "The Phase Analysis of Coal Combustion Residues." Proc., 12th International Conference on Fluidized Bed Combustion, La Jolla, CA, May 9-13, 1993, pp 641-647. 